\title{
The scallop Pedum spondyloideum mitigates the effects of Acanthaster planci predation on the host coral Porites: host defence facilitated by exaptation?
}

\author{
L. M. DeVantier*, R. Endean \\ Department of Zoology, University of Queensland, St Lucia, Brisbane, Queensland 4067, Australia
}

\begin{abstract}
The pectinid scallop Pedum spondyloideum occurs almost exclusively on massive coral colonies of the genus Porites. These scallops have reduced the effects of recent heavy levels of predation by the starfish Acanthaster planci on their coral hosts on the Great Barrier Reef. Scallops repel foraging starfish and other echinoderms on contact by repeated expulsion of jets of water In coral populations subject to heavy predation pressure, this paramutualistic behaviour has resulted in significantly greater survival of host Porites in comparison with congeners without scallops. The survival of corals protected by scallop populations may be important in enhancing recovery and preserving the population structures of these long-lived species. The scallop's expellent water jets function primarily in the removal of wastes. $P$. spondyloideum's secondary application of the jets against $A$. planci and other foraging organisms may thus exemplify an exapted means of host defence.
\end{abstract}

\section{INTRODUCTION}

Population outbreaks of the crown of thorns starfish Acanthaster planci have devastated scleractinian coral communities on many reefs throughout the Indo-West Pacific twice in the last $20 \mathrm{yr}$ (see Moran 1986 for review). Indeed, large feeding aggregations of this otherwise rare species are currently among the most severe forms of disturbance in coral reef ecosystems, causing not only widespread destruction of corals, but also substantial changes in the structure and composition of other reef communities (Chesher 1969, Endean 1973, Endean \& Cameron 1985, Williams 1986, Yamaguchi 1986, Sano et al. 1987).Within coral communities, individual $A$. planci prey selectively upon certain elements of the hard coral assemblage, exhibiting specific preferences based on previous feeding experience (Ormond et al. 1976), palatability, accessibility and prey defences (Barnes et al. 1970, Brauer et al. 1970, Glynn 1980). The interaction of these, and perhaps other, parameters will determine the result of specific

\footnotetext{
- Present address: Australian Institute of Marine Science, PMB 3, Townsville MC, Queensland 4810, Australia
}

predator-prey encounters, and hence the survival of individual corals and their associated fauna.

While many studies have examined the impact of Acanthaster planci on its hard coral prey, there have been relatively few investigations of the potential secondary effects on the hundreds of species associated with hard corals (Patton 1976, Williams 1986, Sano et al. 1987). Yet for many of these species, and particularly for those in obligate associations, their continued survival may be closely linked with survival of the host. During periods of extensive coral mortality, such as that recently caused by $A$. planci on many reefs of the central Great Barrier Reef (GBR) (The Crown-ofThorns Study 1987), any heritable traits of the associate which enhance host survivorship should be subject to natural selection. Such predator-induced selection has been postulated to play a causal role in the evolution of mutualistic associations that can ameliorate the effects of predation (Osman \& Haugsness 1981, Boucher et al. 1982, Endean \& Cameron 1983, Glynn 1983).

Several instances in which coral associates protect their hosts from Acanthaster planci predation have been described (Pearson \& Endean 1969, Weber \& Woodhead 1970, Glynn 1980, 1983). For example, 
decapod crustaceans of the genera Trapezia and Alpheus - obligate commensals of pocilloporid corals in the eastern Pacific - defend their hosts with a variety of aggressive responses initiated by chemical cues from approaching A. planci (Glynn 1980, 1983). Defended corals, which were often avoided by the predator, comprised a substantial proportion of the remnant hard coral assemblage (Glynn 1983). These relations may be coevolved, with both associates evolving beneficial traits interdependently through complementary reciprocal adaptation (Janzen 1980, Glynn 1983).

Alternatively, associates may be pre-adapted (or exapted, sensu Gould \& Vrba 1982) to repel host predators, possessing traits adapted for other functions which fortuitously protect the host from predation. Host defence may thus initially occur as a by-product of the associate-host predator interaction. When expression of an exaptive trait varies within populations, it may in turn be subject to secondary selection. This latter mode of development was recently proposed by DeVantier et al. (1986) for an association between inquiline (nonharmful cohabitant) serpulid worms Spirobranchus giganteus and remnant living coral on host Porites spp. subject to intense predation by Acanthaster planci. The association resulted from an agonistic response by cer- tain worms to contact by A. planci which discouraged predation by the starfish

In this study, we describe a similar positive association between the distribution of inquiline scallops Pedum spondyloideum and surviving host coral tissues on massive colonies of Porites spp. following Acanthaster planci predation (Fig. 1; Done 1987, Fig. 1). $p$. spondyloideum recruits almost exclusively on massive species of Porites throughout the Indo-West Pacific (Yonge 1967, Neilsen 1986, own unpubl. data), their recruitment being a function of larval recognition of these corals from other potential settlement sites, and immunity to, or non-activation of, the corals' anti-fouling defences (Yonge 1967). Thus, for the scallop, the relation is both specialized and obligate. The presence of scallops has previously appeared to confer neither advantage nor disadvantage for the host coral, apart from some minor modifications to growth form (Yonge 1967). However, under heavy predation pressure, survival of the coral may be dependent on the presence of scallops. The ecological significance of the relation for host corals and scallops are discussed in view of these circumstances. The potential importance of the relation for the long-term viability of the Porites associated community is also considered.
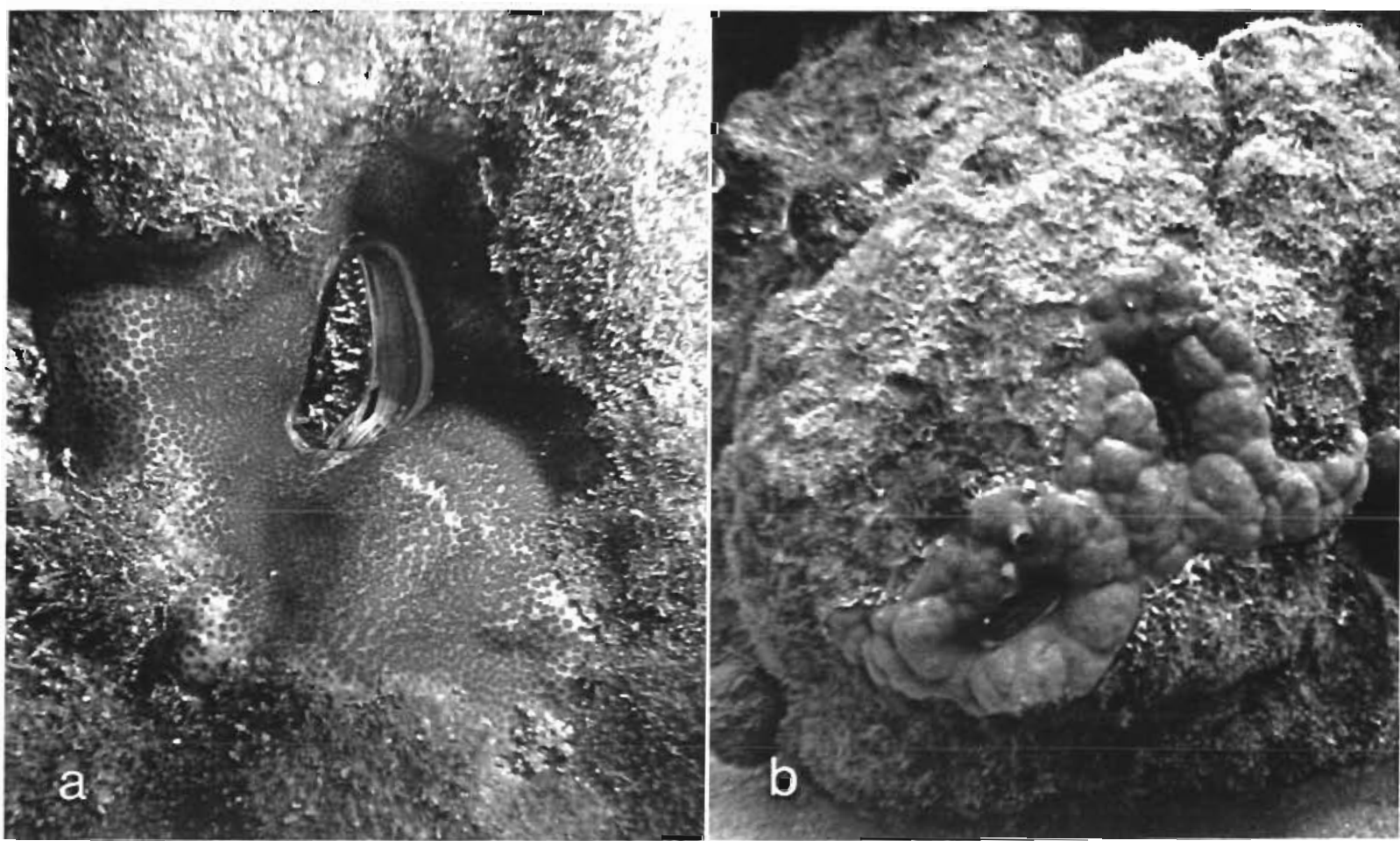

Fig. 1. Remnant patches of living coral tissues surrounding Pedum spondyloideum foliowing Acanthaster planci predation on (a) Holbourne Island Reef, and (b) Potter Reef, Great Barrier Reef (serpulid tube-worms Spirobranchus giganteus are also surrounded by living coral) 


\section{METHODS}

Studies were conducted on Holbourne Island Reef and Keeper Reef, central GBR, during May and July 1987, respectively (Fig. 2). It was estimated that in May 1987 Holbourne Island Reef supported an Acanthaster planci population of the order of 10000 mature starfish (L. Zann pers. comm.), which were actively depleting the hard coral communities. Keeper Reef had supported large aggregations of $A$. planci during the previous several years (The Crown-of-Thorns Study 1987). At the time of this study, a residual $A$. planci population of the order of several hundred individuals was established there (pers. obs.).

To assess the significance of the distribution of Pedum spondyloideum for survival of Porites during an Acanthaster planci outbreak, censuses of massive Porites spp. Colonies within a $10 \mathrm{~m} \times 30 \mathrm{~m}$ belt transect were undertaken at each of 4 sites around Holbourne Island Reef (Fig. 2). The sites were situated in the lee of the prevailing southeast wind and swell in areas of high $A$. planci abundance. At each site, the transect was positioned a randomly selected distance and direction along-slope from the anchoring location, and ranged in depth from 2 to $10 \mathrm{~m}$ below reef crest. Each Porites colony greater than $20 \mathrm{~cm}$ diam. was measured (maximum diam.). Porites lutea, P. lobata, P. solida, $P$. mayeri and $P$. australiensis are the massive Porites species capable of attaining sizes in excess of $20 \mathrm{~cm}$ in diameter in the region of this study (Veron 1986), although no attempt was made to distinguish among these species in the field. Each colony was recorded in 1 of 3 categories based on level of predation: intact, partially consumed, or totally consumed. When $A$. planci were not actively feeding on a colony, mortality was attributed to starfish predation where recent feeding scars were visible, or the dead surfaces were only recently fouled by turf algae. The number of $P$. spondyloideum on the live (including surviving remnants) and/or dead surfaces of all colonies were recorded. On partially consumed corals, the degree of colony mortality was visually estimated to the nearest $10 \%$ of total colony surface.

To simulate the natural interaction of Acanthaster planci with Pedum spondyloideum, 72 starfish (29 to $51 \mathrm{~cm}$ diam.) were placed on the apices of Porites colonies that supported scallops (varying in size from 1.5 to $6.7 \mathrm{~cm}$ valve length) at Holbourne Island Reef and Keeper Reef. The results of starfish encounters with scallops during movement over the corals were recorded as 1 of 4 possible outcomes: (a) no visible change in the behaviour of the scallop (no agonistic response), and no change in the behaviour of the starfish (no aversive reaction); (b) no agonistic response from the scallop, and an aversive reaction from the starfish; (c) agonistic response from the scallop, with no

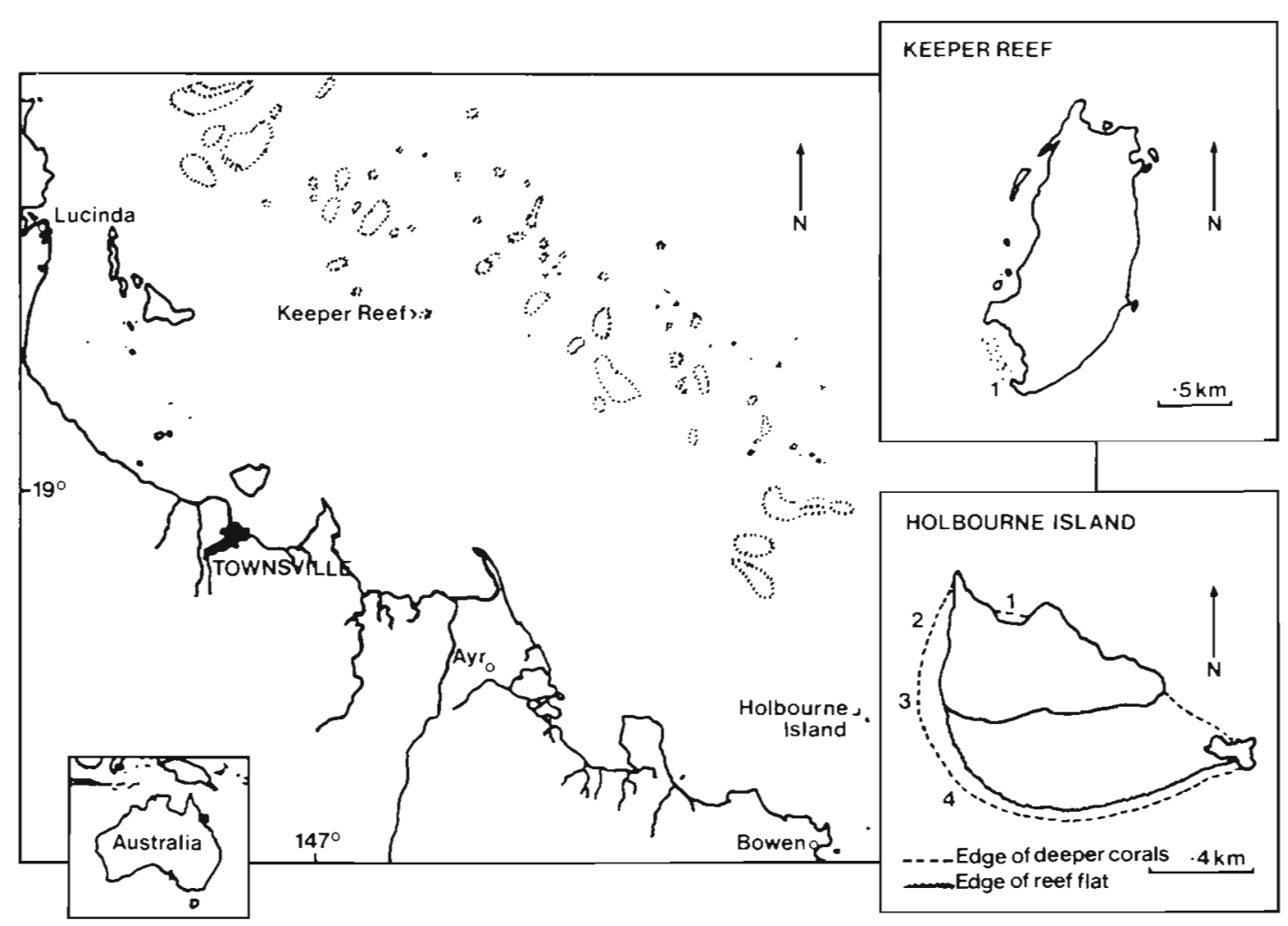

Fig. 2. Locations of survey and experimental sites on Holbourne Island Reef and Keeper Reef, central Great Barrier Reef, 1987 
reaction from the starfish; and (d) agonistic response from the scallop, and aversion by the starfish. Five sets of preliminary tests using the same $8 \mathrm{~A}$. planci and $P$. spondyloideum were also carried out, to assess the potential of scallops and/or starfish exhibiting learned behaviour from repeated contact. To examine the specificity to $A$. planci of any agonistic response from $P$. spondyloideum, similar interaction trials were also conducted with the starfish Linckia laevigata and L. guildingi and the holothurian Thelenota ananas (5 trials in each case). These organisms have been observed to move over Porites in the field (pers. obs.).

\section{RESULTS}

For all coral populations sampled, strong positive associations existed between the distributions of the remaining live Porites colonies and Pedum spondyloideum (Table 1). Scallops were not established on any of the completely consumed corals. Of the 63 corals without scallops, 29 had been completely killed, and predation was continuing on the remaining corals.

The distributions of corals and scallops were extremely patchy both within and between sites. Of the total sample of 120 corals, 57 colonies supported scallops. While often clumped on the coral surface, scallops were established on most colony aspects and thus did not appear to settle preferentially on any particular surface elevation of the host. Of the 57 corals with scallops, 53 colonies subjected to partial predation supported a total of 363 scallops. Among these, 34 colonies supported fewer than 5 scallops each (a total of
71 scallops, of which 68 occurred in remnant live tissues. The coral remnants ranged in size from $10 \mathrm{~cm}^{2}$ rings surrounding individual scallops to larger areas supporting several scallops (Fig. 1). The remaining 19 colonies subject to partial predation supported 5 or more scallops each (a total of 292 scallops, of which all but 2 occurred in remnant live tissues). Of these 19 colonies, 16 had been severely injured by Acanthaster planci predation (50\% or greater mortality). On these 16 colonies there was a highly significant positive association between the distribution of scallops and remnant living coral tissues (chi-square $p<0.001$, Table 2). A similar positive association existed between scallops and remnant living coral on all partially consumed Porites. Only 5 of the 363 scallops censused occurred on surfaces devoid of living polyps. Those corals subject to less than $50 \%$ mortality often possessed other remnant living patches in areas that did not support scallops. This was particularly noticeable on the larger corals, where access by $A$. planci may be more difficult, and water movements more likely to dislodge starfish prior to predation of all living tissues.

The majority of experimental interaction trials resulted in an agonistic response by the scallops to contact by Acanthaster planci, and a subsequent aversive reaction by the starfish (Table 3 ). Contact by starfish usually caused the scallops to generate powerful water jets repeatedly. This behaviour was initiated in response to stimulation of the scallops' sensory pallial tentacles by the tube feet of $A$. planci. It is possible that scallops may also detect starfish in their immediate vicinity from visual (Yonge 1967) or chemical cues. No consistent changes in behaviour indicative of learned

Table 1 Visual census data from 4 sites on Holbourne Island Reef. May 1987. Contingency analyses (Kendall \& Stuart 1979) of occurrence of Pedum spondyloideum on partially versus totally consumed Porites colonies

\begin{tabular}{|c|c|c|c|c|c|}
\hline Site & $\begin{array}{l}\text { State of predation } \\
\text { of colony }\end{array}$ & $\begin{array}{r}\text { Number of } c \\
\text { With }\end{array}$ & $\begin{array}{l}\text { ithout scallops } \\
\text { Without }\end{array}$ & Total & $\begin{array}{c}\text { Fisher Exact } \\
\text { Test } p\end{array}$ \\
\hline 1 & $\begin{array}{l}\text { None } \\
\text { Partial } \\
\text { Complete }\end{array}$ & $\begin{array}{l}1 \\
8 \\
0\end{array}$ & $\begin{array}{l}0 \\
8 \\
7\end{array}$ & $\begin{array}{r}1 \\
16 \\
7\end{array}$ & 0.026 \\
\hline 2 & $\begin{array}{l}\text { None } \\
\text { Partial } \\
\text { Complete }\end{array}$ & $\begin{array}{r}0 \\
12 \\
0\end{array}$ & $\begin{array}{l}0 \\
2 \\
4\end{array}$ & $\begin{array}{r}0 \\
14 \\
4\end{array}$ & 0.005 \\
\hline 3 & $\begin{array}{l}\text { None } \\
\text { Partial } \\
\text { Complete }\end{array}$ & $\begin{array}{r}2 \\
23 \\
0\end{array}$ & $\begin{array}{r}1 \\
13 \\
8\end{array}$ & $\begin{array}{r}3 \\
36 \\
8\end{array}$ & 0.001 \\
\hline 4 & $\begin{array}{l}\text { None } \\
\text { Partial } \\
\text { Complete }\end{array}$ & $\begin{array}{r}1 \\
10 \\
0\end{array}$ & $\begin{array}{r}0 \\
10 \\
10\end{array}$ & $\begin{array}{r}1 \\
20 \\
10\end{array}$ & 0.006 \\
\hline $\begin{array}{l}\text { Total } \\
\text { sample }\end{array}$ & $\begin{array}{l}\text { None } \\
\text { Partial } \\
\text { Complete }\end{array}$ & $\begin{array}{r}4 \\
53 \\
0\end{array}$ & $\begin{array}{r}1 \\
33 \\
29\end{array}$ & $\begin{array}{r}5 \\
86 \\
29\end{array}$ & $<0.001$ \\
\hline
\end{tabular}


Table 2. Contigency analysis (chi-square test, $p<0.001$; Sokal \& Rohlf 1969) of distribution of Pedum spondyloideum on partially consumed Porites colonies on Holbourne Island Reef (May 1987)

\begin{tabular}{|lcrcr|}
\hline $\begin{array}{l}\text { Colony } \\
\text { diameter } \\
(\mathrm{m})\end{array}$ & $\begin{array}{c}\text { Colony } \\
\text { damage } \\
(\%)\end{array}$ & $\begin{array}{c}\text { Nos. of P. spondy- } \\
\text { loideum present in live } \\
\text { and dead coral } \\
\text { Live }\end{array}$ & Dotal \\
\hline \multicolumn{4}{c}{ Dead } \\
2.48 & 50 & 10 & 1 & 11 \\
3.50 & 50 & 8 & 0 & 8 \\
0.35 & 50 & 18 & 0 & 18 \\
1.61 & 60 & 6 & 0 & 6 \\
3.75 & 60 & 14 & 0 & 14 \\
1.06 & 60 & 21 & 0 & 21 \\
3.17 & 70 & 24 & 0 & 24 \\
0.43 & 70 & 14 & 0 & 14 \\
0.54 & 80 & 6 & 1 & 7 \\
5.16 & 80 & 5 & 0 & 5 \\
0.38 & 80 & 8 & 0 & 8 \\
1.68 & 90 & 5 & 0 & 5 \\
2.71 & 90 & 7 & 0 & 7 \\
2.85 & 90 & 5 & 0 & 5 \\
4.41 & 90 & 35 & 0 & 35 \\
& 90 & 18 & 0 & 18 \\
& Total & 204 & 2 & 206 \\
\hline
\end{tabular}

responses from either starfish or scallops were evident during the preliminary course of repeated interaction trials.

The expellent water currents, identical to those used in the expulsion of pseudofaeces and sediments, are generated by brief contractions of the adductor muscle and channelled through an opening in the mantle margin (Yonge 1967) (Fig. 3). Impact of the jets usually caused starfish to retract the sensory tube feet at the tips of the affected arm, raise the arm, and in most instances move away. However, in several interactions, starfish persisted in moving onto or over the scallop following initiation of the jets. On 2 occasions, this resulted in the starfish being lifted several $\mathrm{cm}$ above the coral surface by the continuing jets.

Interactions of Pedum spondyloideum with Linckia laevigata, L. guildingi and Thelenota ananas usually produced an agonistic response from the scallops similar to that elicited by Acanthaster planci. This agonistic response was usually followed by an aversive reaction from the echinoderms. Contact by Acanthaster planci, Linckia spp. and $T$. ananas did not always elicit a response from the scallops and, in some instances, the echinoderms continued to move over the scallops. However, even when an agonistic response from the scallops was not apparent the echinoderms sometimes exhibited aversive behaviour (as documented for $A$. planci in Table 3)

\section{DISCUSSION}

It would appear that the repellent water jets of Pedum spondyloideum sufficiently irritate Acanthaster planci and other foraging echinoderms to produce an aversive response that discourages predation on the adjacent coral tissues. That irritation of the tube feet or everted stomach discourages feeding in $A$. planci and other asteroids is well documented (Barnes et al. 1970, Binyon 1972, Glynn 1980, Valentincic 1983). P. spondyloideum produces the jets as a means of deterring foraging echinoderms in general, rather than as a specific response to $A$. planci. The scallop's alternate response - immediate closure of the valves, and withdrawal into the security of the scallop-modified crevice - is initiated by other stimuli (Yonge 1967), such as positioning a hand over the scallop (pers. obs.). $P$. spondyloideum is therefore capable of differentiating among potential threats, probably by utilizing both tactile and visual stimuli.

The scallops did not always react to contact by Acanthaster planci during the interaction trials (Table 3 ). Whether this was an artifact of the experimental manipulation of the starfish (which did not attempt to feed during the tests), or an indication of phenotypic or genotypic variability within the scallop population, is unclear. The field census data demonstrate that Pedum spondyloideum was usually surrounded by living coral,

Table 3. Contigency analysis (chi-square test for independence; Conover 1980) of experimental interactions between Acanthaster planci and Pedum spondyloideum on Holbourne Island Reef (May 1987) and Keeper Reef (July 1987)

\begin{tabular}{|c|c|c|c|c|c|}
\hline \multirow[t]{2}{*}{ Reef } & \multirow{2}{*}{$\begin{array}{l}\text { P. spondyloideum } \\
\text { response }\end{array}$} & \multicolumn{2}{|c|}{ A. planci response } & \multirow{2}{*}{$\begin{array}{l}\text { Total no. of } \\
\text { interactions }\end{array}$} & \multirow{2}{*}{$\begin{array}{l}\text { Chi-square } \\
\text { probability } p\end{array}$} \\
\hline & & Yes & No & & \\
\hline Holbourne & Yes & 22 & 2 & & \\
\hline Is. Reef & No & 5 & 11 & 40 & $<0.001$ \\
\hline Keeper & Yes & 15 & 4 & & \\
\hline Reef & No & 6 & 7 & 32 & $<0.005$ \\
\hline
\end{tabular}




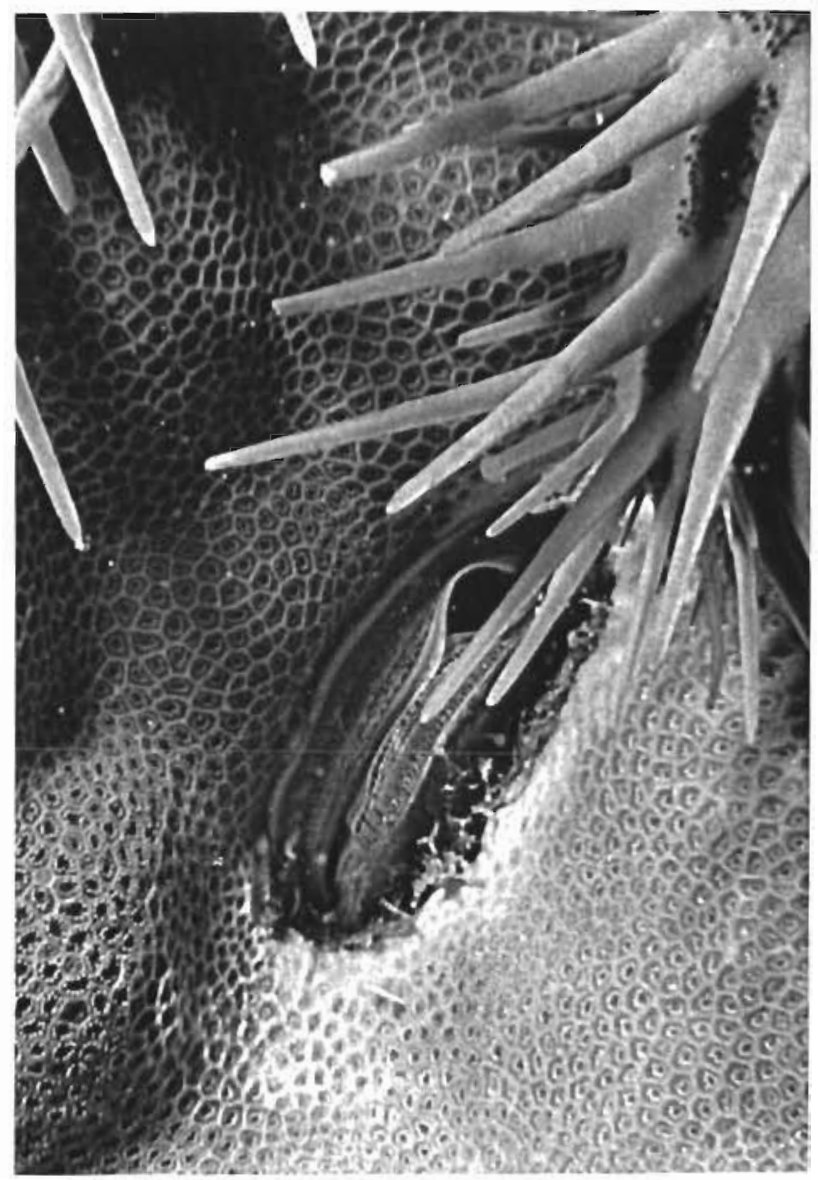

Fig. 3. Interaction of Acanthaster planci with Pedum spondyloideum. Initiation of expellent current is indicated by the scallop's open valves, frilled lips and mantle opening

which would suggest that scallops on Holbourne Island Reef generally were successful in deterring $A$. planci from feeding. This in turn suggests that the scallops' failure to react to $A$. planci during the tests was an experimental artifact.

During Acanthaster planci outbreaks, regular contact between Pedum spondyloideum and A. planci may result in the development of learned behavioural responses by the scallops or starfish, although preliminary tests using the same individuals did not indicate this. A. planci does have a capacity to 'learn', as demonstrated by the development and recall of preferences for particular prey coral species over a 2 mo period (Ormond et al. 1976). It seems likely that the outcome of each interaction will vary in relation to the nutritional and physiological status of the predator, to prey availability and to the population densities of starfish and scallops. For instance, feeding and avoidance behaviour in another starfish, Marthasterias glacialis, are flexible. Even when an avoidance response was firmly established, initiation of a feeding response predominated on certain occasions (Valentin- cic 1978). Future research will include repeated interaction trials to determine whether $A$. planci can identify and recall an aversive reaction to a coral associate with a particular host coral species.

While several Porites species are the primary habitat of Pedum spondyloideum, these scallops also occur rarely in other massive corals, particularly species of the faviid genus Goniastrea. Living coral remnants have been observed to surround the scallops on these corals following Acanthaster planci predation. Relict patches of living coral also occasionally surround other inquiline species, particularly the bivalves Navicula sp., Barbatia sp., Tridacna croced, and the hermit crab Paguritta sp. (which may occupy Spirobranchus giganteus tubes). The interactions of these species with $A$. planci have not yet been investigated. However, in describing the habitats of the bivalves associated with massive Porites, Yonge (1967) noted that species other than $P$. spondyloideum were usually attached to dead surfaces: 'Pedum appears unique in it's intimate association with living coral. It has more in common with the serpulids' (S. giganteus, Fig. 1b). While certain worms within the $S$. giganteus species complex are capable of repelling $A$. planci (DeVantier et al. 1986), these were uncommon on Holbourne Island Reef, and thus made little contribution to the survival of Porites on this reef.

At the time of censusing, Holbourne Island Reef was in the middle stages of an Acanthaster planci outbreak. and still supported substantial, though diminishing areas of living coral. At that time, a considerable number of Ponites colonies had been subject to predation causing less than 50\% mortality. Agonistic behaviour by Pedum spondyloideum will be most significant in ensuring the survival of those corals subject to intense predation. Field observations of Porites populations on reefs in the central GBR subject to heavy A planci predation in the early 1980s (Green Island Reef, Potter Reef and John Brewer Reef) have indicated that both $P$. spondyloideum and the protected polyps often continued to grow following predation (Fig. 1b). Thus, the long-term consequences of the interaction between $A$. planci and $P$. spondyloideum would appear to be the continued survival and growth of both the colony and the bivalve.

The long-term survival of individual Porites colonies is an important trait in the life histories of these iteroparous species (Cameron \& Endean 1985, Done $1985,1987)$. At an average annual growth rate of $1 \mathrm{~cm}$ $\mathrm{yr}^{-1}$ radially in the region of this study ( $\mathrm{P}$. Isdale pers. comm.), the larger coral colonies examined had survived for at least 150 to $200 \mathrm{yr}$ (Table 2). Indeed, massive Porites are some of the longest-lived and largest of all corals (Isdale 1984, Potts et al. 1985), capable of producing millions of gametes annually (Kojis \& Quinn 1981, Harriott 1983). The surviving corals should con- 
tribute to the recovery of Porites populations, both through localized dispersal via fragmentation (Highsmith 1982) (probably enhanced by partial mortality). and further afield through continued, albeit reduced, contributions to the gamete pool (Highsmith 1980, Oliver \& Willis 1987). The persistence of protected corals should buffer Porites populations against continuing outbreaks of Acanthaster planci

Protection of adjacent polyps from Acanthaster planci predation may also provide long-term benefit to the scallops, as growth of the surrounding coral tissue should enhance their continued survival. Partially embedded in their host's expanding skeleton, scallops filter-feed above the lower strata of benthos, and appear to be relatively secure from predation. How ever, when host Porites die, it is likely that the continued growth of immature scallops above the dead coral surface will result in their becoming more exposed to predators. The continuing bioerosion of dead colonies would also lead to greater exposure of the scallops. The likelihood of fouling or overgrowth of scallops by other sessile species will also increase Fouling of adjacent dead coral surfaces occasionally results in the formation of clones of 'daughter colonies' surrounding individuals or groups of Pedum spondyloideum. The daughter colonies may eventually fuse, masking the original predation scars (Done 1987). This will be dependent upon the degree of damage, the distribution of the Porites remnants and interactions with the developing epilithic assemblage. As living Porites colonies appear to be the preferred settlement substrata for $P$. spondyloideum larvae (Yonge 1967), the continued growth of protected coral should provide suitable habitats for larval colonization and hence maintenance of local scallop populations. In the longer term, the action of $P$. spondyloideum in repelling $A$. planci tends to ensure that recruitment refugia are provided for their larvae following starfish predation, thus favouring the continuity of these populations.

Under continued outbreaks of Acanthaster planci, the Pedum-Porites relation may have broader longterm implications for other obligate and facultate associates of Porites. These corals are important species for many other reef organisms. In addition to $A$. planci, Porites provide nutrition for teleost (chaetodontids and labrids) and gastropod predators (Drupella spp.) (pers. obs.). Several other species feed on bacteria and detritus trapped in the mucus secreted by living Porites, notably the nudibranch Chelidonura inornata (Rudman 1984, pers. obs.).

Living Porites are the preferred settlement sites not only of Pedum spondyloideum, but also of Spirobranchus giganteus larvae (Smith 1985), while a diverse range of molluscs bore in, or inhabit crevices on, these corals (Nielsen 1986). Large Porites also provide shelter and protection for a diverse range of taxa. Site-attached and home-ranging fishes such as the barramundi cod Cromileptes altivelis, six-banded angel fish Euxiphipops sexstriatus and groper Promicrops lanceolatus, a species of octopus, the spiny lobster Panuliris ornatus and other crustaceans, and green and loggerhead turtles Chelonia midas and Caretta caretta respectively, all use the crevices and basal ledges of these corals for shelter (DeVantier \& Endean unpubl.). The cleaner wrasse Labroides dimidiatus also often establish cleaning stations around these corals, suggesting that teleosts may use such large distinctive colonies for orientation (Hobson 1973). In fulfilling these roles, such longlived corals form the basis of complex coral reef communities (Cameron \& Endean 1985). In Porites populations subject to intense Acanthaster planci predation, the survival and continued growth of host colonies from polyps protected by adjacent Pedum spondyloideum may tend to buffer the longer-term secondary impacts of the starfish on a wide range of associated species.

The mechanism used by Pedum spondyloideum to repel Acanthaster planci appears to be an exapted (Gould \& Vrba 1982) rather than an adapted means of defence. The scallops repel starfish by generating water jets that are identical to cleansing currents used in the removal of wastes and sediments (Yonge 1967). The defensive success of $P$. spondyloideum has thus been facilitated by a mechanism which functions primarily for the discharge of wastes, rather than for host protection. Features co-opted as exaptations may be adaptations for another function or they may serve no purpose ('non-aptive') (Gould \& Vrba 1982). In this case, the defensive exaptation appears to have been co-opted from an adaptation for waste removal.

Similar examples of the use of exhalent jets for defensive purposes can be found in other bivalves (Purchon 1977). For example, the reef clam Tridacna maxima directs jets from the exhalent siphon that dislodge foreign objects and drive away predators from the otherwise defenceless mantle tissues (Stasek 1965). Free-living scallops also employ exhalent jets to escape from asteroid predators (Binyon 1972). This raises the possibility that the exapted defensive mechanism of Pedum spondyloideum arose early in bivalve evolution and thus existed prior to the adoption of an inquiline mode of life. As noted by Gould (1983), 'Genetic systems are integrated products of an organism's history, and they retain extensive, latent capacities that can often be released by small changes'. In this manner, facultative mutualisms may arise initially from fortuitous exaptations which enhance host survivorship.

Acknowledgements. This study benefitted from discussions with Dr Ann M. Cameron of the University of Queensland, and Drs T. J. Done, J. A. H. Benzie, P. J. Moran, R. E. Reichelt, 
R. H. Bradbury, J. A. Stoddart, C. R. Wilkinson, P. Isdale and J Pandolfi of the Australian Institute of Marine Science. C. N. Mundy, S. M. Davies, I. Bush, K. A. Day, J. K. Keesing, M. Haseler, M. Stafford Smith, J. Kleypas, R. Van Woesik, A. Meltzer, K. Weaver, G. Andrews and 3 reviewers also provided helpful advice. We acknowledge gratefully the use of the facilities of the Australian Institute of Marine Science during the course of this research.

\section{LITERATURE CITED}

Barnes, D. J., Brauer, R. W., Jordan, M. R. (1970). Locomotory response of Acanthaster planci to various species of coral. Nature, Lond. 228: 342-344

Binyon, J. (1972). Physiology of echinoderms. Pergamon Press, Oxford

Boucher, D. H., James, M., Keeler, K. H. (1982). The ecology of mutualism. Ann. Rev. Ecol. Syst. 13: 315-347

Brauer, R. W., Jordan, M. R., Barnes, D. J. (1970). Triggering of the stomach eversion reflex of Acanthaster planci by coral extracts. Nature, Lond. 228: 344-346

Cameron, A. M., Endean, R. (1985). Do long-lived species structure coral reef ecosystems? Proc. 5th Int. Coral Reef Congr. 6: 211-215

Chesher, R. H. (1969). Destruction of Pacific corals by the sea star Acanthaster planci. Science 165: 280-283

Conover, W. J. (1980). Practical nonparametric statistics, 2nd edn. John Wiley and Sons, Inc., New York

DeVantier, L. M., Reichelt, R. E., Bradbury, R. H. (1986). Does Spirobranchus giganteus protect host Porites from predation by Acanthaster planci: predator pressure as a mechanism of coevolution? Mar Ecol. Prog. Ser. 32: $307-310$

Done, T J. (1985). Effects of two Acanthaster outbreaks on coral community structure - the meaning of devastation. Proc. 5th Int. Coral Reef Congr. 5: 315-320

Done, T J. (1987). Simulation of the effects of Acanthaster planci on the population structure of massive corals of the genus Porites: evidence of population resilience? Coral Reefs 6: 75-90

Endean, R. (1973). Population explosions of Acanthaster planci and associated destruction of hermatypic corals in the Indo-West Pacific region. In: Jones, O. A., Endean, R. (eds.) Biology and geology of coral reefs, Vol. 2. Biology 1. Academic Press, New York, p. 389-438

Endean, R., Cameron, A. M. (1983). Toxins in coral reef organisms. Toxicon. Suppl. 3: 105-109

Endean, R., Cameron, A. M. (1985). Ecocastrophe on the Great Barrier Reef. Proc. 5th Int. Coral Reef Congr. 5: 309-314

Glynn, P. W. (1980). Defence by symbiotic Crustacea of host corals elicited by chemical cues from the predator Oecologia (Berl.) 47. 287-290

Glynn, P. W. (1983). Crustacean symbionts and the defence of corals: coevolution on the reef? In: Nitecki, M. H. (ed.) Coevolution. University of Chicago Press Ltd, Chicago, p. $111-178$

Gould, S. J., Vrba, E. S. (1982). Exaptation - a missing term in the science of form. Paleobiology 8: 1-15

Gould, S. J. (1983). Hen's teeth and horse's toes. W W. Norton and Co., New York

Harriott. V. J. (1983). Reproductive ecology of four scleractinian species at Lizard Island, Great Barrier Reef. Coral Reefs 2: 9-18

Highsmith, R. C. (1980). Passive colonization and asexual colony multiplication in the massive coral Porites lutea Milne Edwards and Haime. J. exp. mar. Biol. Ecol. 47: $55-67$

Highsmith, R. C. (1982). Reproduction by fragmentation in corals. Mar. Ecol. Prog. Ser. 7: 207-226

Hobson, E. S. (1973). Diel feeding migrations in tropical reef fishes. Helgoländer wiss. Meeresunters. 24: 361-370

Isdale, P. (1984). Fluorescent bands in massive corals record centuries of coastal rainfall. Nature, Lond. 310: 578-579

Janzen, D. H. (1980). When is it coevolution? Evolution 34 $611-612$

Kendall, M., Stuart, A. (1979). The advanced theory of statistics, Vol.2 Inference and relationship, 4th edn. Charles Griffin and Co., London

Kojis, B. J., Quinn, N. J. (1981). Reproductive strategies in four species of Porites (Scleractinia). Proc. 4th Int. Coral Reef Symp. 2: $145-151$

Moran, P. J. (1986). The Acanthaster phenomenon. Oceanogr mar Biol. A. Rev. 24: 379-480

Nielsen, C. (1986). Fauna associated with the coral Porites from Phuket, Thailand. (Part 1): Bivalves with description of a new species of Gastrochaena. Phuket marine biol. Centre Res. Bull. 42: 1-24

Oliver, J. K., Willis, B. J. (1987). Coral-spawn slicks in the Great Barrier Reef: preliminary observations. Mar. Biol. 94: 521-530

Osman, R. W., Haugsness, J. A. (1981). Mutualism among sessile invertebrates: a mediator of competition and predation. Science 211: 846-848

Ormond, R. F. G., Hanscomb, N. J., Beach, D. H. (1976). Food selection and learning in Acanthaster planci. Mar. Behav. Physiol. 4: 93-105

Patton, W K. (1976). Animal associates of living corals. In: Jones, O. A., Endean, R. (eds.) Biology and geology of coral reefs, Val. 3, Biology. Academic Press, New York, p. 1-36

Pearson, R. G., Endean, R. (1969). A preliminary study of the coral predator Acanthaster planci (L.) (Asteroidea) on the Great Barrier Reef. Queensl. Fish. Notes 3: 27-55

Potts, D. C., Done, T. J., Isdale, P. J., Fisk, D. A. (1985). Dominance of a coral community by the genus Porites (Scleractinia). Mar. Ecol. Prog. Ser. 23: 79-84

Purchon, R. D. (1977). The biology of the Mollusca. Pergamon, Oxford

Rudman, W B. (1984). Molluscs. In: Readers Digest book of the Great Barrier Reef. Readers Digest, Sydney, p. 124

Sano, M., Shimizu, M., Nose, Y (1987). Long-term effects of destruction of hermatypic corals by Acanthaster planci infestation on reef fish communities at Iriomote Island, Japan. Mar Ecol. Prog. Ser. 37. 191-199

Smith, R. (1985). Development and settling of Spirobranchus giganteus (Polychaeta; Serpulidae). Proc. 1st Int. Polychaete Conference, Sydney: 461-483

Sokal, R. R., Rohlf, F. J. (1.969). Biometry. W. H. Freeman and Co, San Francisco

Stasek, C. R. (1965). Behavioural adaptation of the giant clam Tridacna maxima to the presence of grazing fishes. Veliger 8: $29-35$

The Crown-of-Thorns Study (1987). Townsville Sector. The Crown-of-Thorns Study (1985). An assessment of the distribution and effects of Acanthaster planci (L) on the Great Barrier Reef, Vol. 8. Australian Institute of Marine Science, Townsville

Valentincic, $T$ (1978), Learning in the starfish Marthasterias glacialis. In: McLusky, D. J., Berry, A. J. (eds.) Physiology and behaviour of marine organisms. Pergamon Press, Oxford, p. 303-309

Valentincic, I (1983). Innate and learned responses to exter- 
nal stimuli in asteroids. In: Jangoux, M., Lawrence, J. M. (eds.) Echinoderm studies. A. A. Balkema, Rotterdam, p. $111-138$

Veron, J. E. N. (1986). Corals of Australia and the Indo-Pacific. Angus and Robertson, Australia

Weber, J. N., Woodhead, P. M. J. (1970). Ecological studies of the coral predator Acanthaster planci in the South Pacific. Mar. Biol. 6: 12-17

Williams, D. McB. (1986). Temporal variation in the structure of reef slope fish communities (central Great Barrier Reef) short-term effects of Acanthaster planci infestation. Mar Ecol. Prog. Ser 28: 157-164

Yamaguchi, M. (1986). Acanthaster planci infestations of reefs and coral assemblages in Japan: a retrospective analysis of control efforts. Coral Reefs 5: 23-30

Yonge, C. M. (1967). Observations of Pedum spondyloideum (Chemintz) Gmelin, a scallop associated with reef-building corals. Proc. malac. Soc. Lond. 37: 311-323

This article was submitted to the editor; it was accepted for printing on June 3, 1988 